\title{
Structure Activity Relationship (SAR) Studies on the Tricyclic Antidepressor Compounds Marketed in Turkey. II*
}

\author{
Türkiyede Satılan Trisiklik Antidepresör Bileşikler \\ Úzerinde Yapı Etki İlişsisi Araştırmaları. II*
}

\section{Ningur NOYANALPAN**}

\section{INTRODUCTION}

Tricyclic compounds consititute an important class of the antidepressor medicinals ${ }^{1}$. One of the rings in these compounds is seven membered. This seven membered ring has a nitrogen atom in azepin derivatives, two nitrogen atoms in diazepin derivatives, an oxygen atom in oxepin derivatives or all-carbon in cycloheptatrien derivatives.

Various analytical aspects of tricyclic antidepressor compounds have been investigated. Among these thin layer chromatography separation methods, (2-8) quantitative determinations with ultraviolet spectrophotometer, (9-11) colorimetric determinations (12), and separations with tlc using azeotrop mixtures (6) can be mentioned.

More than one goal have been considered in undertaking this research. First of all it is quite evident in present time that one can produce valuable informations about the mechanisms of effect of the medicinals by using the SAR methods (13). In fact from time to time with the SAR methods an unusual behaviour of the organism can be brought to the level of comprehension, i.e. in this research the compounds which were the subject to study have been accumulated along two lines of different $\mathrm{a}_{1}$ and $\mathrm{a}_{0}$ values and also of diffe-

\footnotetext{
Redaksiyona verildiği tarih: 30 Mays 1978

* for previous paper see. This Journal 8, 801978

** Farmasötik Kimya Kürsüsü, Eczacıllk Fakültesi, Ankara Úniversitesi.
} 
rent $\mathrm{r}$ and $\mathrm{s}$ values. Considering this feature one may conclude that these compounds produce their effects in the organism by interacting with two different species of enzymes or in short with two different mechanisms. Another feature of this research is the applicability in practice. The cost of biological tests is getting higher everyday. Therefore it is very desirable to establish some means of estimating the quantity of a new compound that produces a respond in a biological system, before commencing the experiments. This would save a lot of time and waste of money. With this research it now seems possible to estimate the dosage of a new compound having the same structural and biological properties before starting a biological experiment.

For the sake of SAR studies a number of parameters have been used. (14-18) One of these parameters which is most frequently and successfully used is the $\log$ P. $(19,20)$, Others have not been exploited that much. In this research n-octanol has been used as the organic phase for the determination of partition coefficients. For this determination a preliminary procedure was required. All of the compounds are salts of various kinds. Therefore they had to be transformed into organic bases to provide their solubility in organic medium. But this transformation had to be in such a way as to simulate the biological medium. Thus all of the compounds have been dissolved in water, the $\mathrm{pH}$ of the solution has been brought to 7.8 and the partition coefficients have been determined using these aqueous solutions and $\mathrm{n}$-octanol. This $\mathrm{pH}$ value is the closest to that of the biological medium where the absorbtion of such compounds is the highest.

After the determination of $\log \mathrm{P}$ of each compond the graphs have been drawn, by using allways the $\log \mathrm{P}$ values on the abscissa and either $\mathrm{LD}_{50}$ (Molar concentration) itself or logarithmic values of it on the ordinate.

Also a series of chromatographic studies has been done to find out the solvent system that gives the best separation. After calculating $R_{M}$ values graphs have been drawn by plotting them versus $\mathrm{LD}_{50}$ (M.C.). . Although the graphs are similar to Graph I the correlations are not as good. 


\section{EXPERIMENTAL}

All of the compounds processed in this research have been medicinal degree pure, melting point and IR spectrum of each compound have been compared with the catalog data. All of the solvents have been supplied from Merck, Riedel or Aldrich. n-octanol has been purified by column distillation over $\mathrm{NaOH}$. The ultraviolet spectrophotometer has been a Pye-Unicam SP-1700. The melting points have been determined with a Büchi SMP-20 apparatus and given without correction. In thin layer chromatography studies a mixture of Kieselgel G and Kieselgel HF $254(90+10)$ has been used on the plates of dimensions $10 \times 10 \mathrm{~cm}$ or $20 \times 20 \mathrm{~cm}$ with a layer thickness of $0.3 \mathrm{~mm}$. The plates have been run in tanks of $20 \times 20$ $\mathrm{cm}$ dimensions checked under UV light then sprayed with vanillin reagent.

Entire calculations have been performed with a TI-58 programmable calculator equipped with a PG-100 A.

\section{Derivation of Standard Lines}

$10.0 \mathrm{mg}$ from each compound has been weighed precisely, where weighing precisely was not possible a larger amount was dissolved in water and corresponding amount in millilitres has been abstracted. The aqueous solution containing $10.0 \mathrm{mg}$ of compound has been brought to a volume close to $50 \mathrm{ml}$. The $\mathrm{pH}$ of the solution was adjusted to 7.8 by $0.01 \mathrm{~N} \mathrm{NaOH}$ solution. When the $\mathrm{pH}$ adjustment was completed the volume of the solution was precisely $50.0 \mathrm{ml}$.

Starting from these solutions primarily standard graphs have been prepared. Three different dilutions have been used at a time. $1.0 \mathrm{ml}$ from each solution has been diluted to $10.0 \mathrm{ml} .20 .0 \mathrm{ml}$ and $40.0 \mathrm{ml}$. A part of each solution has been transfered into a UV chamber of $1 \mathrm{~cm}$ pathlength, the absorbances have been measured at certain wavelengths. Using the absorbance values at different dilutions standard graphs have been prepared and also parameters have been derived. 


\section{Determination of Partition Coefficients}

Precisely $25.0 \mathrm{ml}$ has been taken from the $50.0 \mathrm{ml}$ solution of compound (thus $5.0 \mathrm{mg}$ ). $25.0 \mathrm{ml} \mathrm{n}$-octanol has been added to this solution. The flask has been placed in a water bath at a constant temperature of $40^{\circ} \mathrm{C}$. Meanwhile the inner temperature has been kept at $37^{\circ} \mathrm{C}$. The solution was constantly stirred with a magnetic bar. The stirring and heating continued for 24 hours. Then the flask was removed frcm bath, cooled at room temperature. After the layers separated the solution was transfered into centrifuge tubes and centrifuged till perfect clearity.

$1.0 \mathrm{ml}$ has been taken from the octanol layer, transfered into a measured flask and completed to $20.0 \mathrm{ml}$ with n-octanol. Sufficient amount of this solution has been taken into a UV chamber of $1 \mathrm{~cm}$ pathlength and absorbances were measured as before for the determination of standard lines.

Again $1.0 \mathrm{ml}$ has been taken from aqueous layer, transfered into a measured flask and completed to $20.0 \mathrm{ml}$ with distilled water. Sufficient amount has been taken into a UV chamber of $1 \mathrm{~cm}$ pathlength and again absorbances have been read at appropriate wavelengths.

For the construction of graphs and derivation of appropriate equations these values have been employed.

The values found have been carried on standard graphs, the bisecting points gave quantities directly. But it was not possible to read beyond the second decimal whereas the results are magnified either 400 or 500 times respectively to reach the quantities in mother liquours. Therefore a mathematical means of calculation has been derived using the slopes of standard lines.

\section{RESULTS}

The compounds which have been used in this research have been exhibited in Table I, along with their melting points determined during the study, their $\mathrm{LD}_{50}$ values reported in the literature and their $\mathrm{LD}_{50}$ molar concentrations, $\mathrm{LD}_{50(\mathrm{M} . \mathrm{C.})}$. A uniformity has been provided in choosing the $\mathrm{LD}_{50}$ values. Only those for the 
Table I. The compounds with their code numbers assigned in this research, melting points, $\mathrm{pH}$ of aqueous solutions $(10 \mathrm{mg} / 50 \mathrm{ml}), \mathrm{LD}_{50}$ values mice oral, $\mathrm{LD}_{50}$ molar concentrations $(x 10-3)$, and $\log 1 / L_{50}$ (M.c.)

\begin{tabular}{|c|c|c|c|c|c|c|}
\hline $\begin{array}{l}\text { Code } \\
\text { num. }\end{array}$ & Name & $\begin{array}{c}\text { melting } \\
\text { point } \\
{ }^{\circ} \mathrm{C}\end{array}$ & \begin{tabular}{|c|}
$\mathrm{pH}$ of \\
$10 \mathrm{mg} / 50 \mathrm{ml}$ \\
$\mathrm{aqu}$. \\
sol.
\end{tabular} & $\begin{array}{l}\mathrm{LD}_{30} \\
\text { mice, oral, } \\
\text { mg. } \\
\text { and ref. }\end{array}$ & $\begin{array}{c}\mathrm{LD}_{50}, \\
\text { Molar } \\
\text { concentra- } \\
\text { tion }\left(\mathrm{x}^{10^{-3}}\right)\end{array}$ & $\begin{array}{l}\log 1 / \\
\mathrm{LD}_{50} \\
\text { (M.c.) }\end{array}$ \\
\hline 1 & Imipramine & $167-168$ & 6.36 & $660^{21}$ & 2.0829 & 2.6813 \\
\hline 2 & Amitriptyline & $189-190$ & 6.20 & $280^{22}$ & 0.8921 & 3.0496 \\
\hline 3 & Desipramine & $208-210$ & 6.24 & $572^{26}$ & 1.8808 & 2.7238 \\
\hline 4 & Dibenzepin & $236-237$ & 6.43 & $215^{24}$ & 0.6479 & 3.1884 \\
\hline 5 & Doxepin & $180-182$ & 6.40 & $135^{25}$ & 0.4274 & 3.3691 \\
\hline 6 & Nortriptyline & $212-213$ & 5.92 & $327^{22}$ & 1.0906 & 2.9623 \\
\hline 7 & Trimipramine & 138 & 5.49 & $250^{22}$ & 0.6090 & 3.2154 \\
\hline 8 & Opipramol & $216-217$ & 3.81 & $700^{22}$ & I. 6040 & 2.7948 \\
\hline 9 & Chlorimipramine & $188-189$ & 6.42 & $320^{26}$ & 0.9108 & 3.0406 \\
\hline 10 & Protriptyline & $164-166$ & 6.88 & $269^{22}$ & 0.8971 & 3.0471 \\
\hline
\end{tabular}

mice and determined per os have been taken into consideration. In Table II, all the wavelengths at which the absorbances have been read, the absorbances at three different wavelengths or two different wavelengths and the parameters which have been derived from these absorbances have been given.

The parameters have been derived as additional data because they give sounder results. On the graphs only the numbers consisting of two digits can be read out directly but any further reading is not trustable. More detailed values are desirable as the result magnifies many times when passing to the quantity of compounds either in octanol or water layer. Further on the Table II the quantities which were found spectroscopicly have been given. As it is seen from the table both the octanol and water layers have been measured to reduce the error.

In Table III the total quantity of compounds in octanol and water layer together with their partion coefficients and logarithms have been given.

Graph I has been constructed using the data given in Table $\mathrm{I}$, II and III by plotting $\log \mathrm{P}$ values versus $\mathrm{LD}_{\mathrm{so}(\mathrm{M} \cdot \mathrm{cc})}$. According to Graph I six out of ten compounds were accumulated an a straight line which means there is a linear correlation among those compounds. The remaining four compounds also show a linear correlation at a different value and different parameters. Graph II and Graph III also show linear correlations by plotting again $\log \mathrm{P}$ values versus 
Table II. Compounds with their wavelengths, dilutions, absorbances, parameters, and absorbances in octanol and water layers, quantities found.

\begin{tabular}{|c|c|c|c|c|c|c|c|c|}
\hline \multirow{2}{*}{$\begin{array}{l}\text { wave } \\
\text { length } \\
\text { in } \mathrm{nm}\end{array}$} & \multicolumn{3}{|c|}{ dilutions } & \multirow{2}{*}{$\begin{array}{l}\text { param- } \\
\text { eter }\end{array}$} & \multirow{2}{*}{\multicolumn{2}{|c|}{$\begin{array}{l}\text { absorbance, } \\
\text { amount in octano }\end{array}$}} & \multirow{2}{*}{\multicolumn{2}{|c|}{$\begin{array}{l}\text { absorbance, } \\
\text { amount in wate }\end{array}$}} \\
\hline & \multicolumn{3}{|c|}{ Imipramin } & & & & & \\
\hline 212 & 1.582 & 0.791 & 0.395 & 0.791 & 0.4081 & 0.516 & 0.3828 & 0.484 \\
\hline 253 & 0.484 & 0.242 & 0.121 & 0.242 & 0.1248 & 0.516 & 0.1171 & 0,484 \\
\hline 276 & 0.386 & 0.193 & 0.0965 & 0.193 & 0.0995 & 0.516 & 0.0934 & 0.484 \\
\hline & Amitr & tiline & & & & & & \\
\hline 208 & 1.709 & 1.106 & 0.553 & 1.106 & 0.5596 & 0.506 & 0.5463 & 0.494 \\
\hline 241 & 0.774 & 0.387 & 0.194 & 0.387 & 0.195 & 0.506 & 0.191 & 0.494 \\
\hline & Desim & ramin & & & & & & \\
\hline 212 & 1.405 & 0.698 & 0.348 & 0.698 & 0.335 & 0.480 & 0.362 & 0.520 \\
\hline 252 & 0.418 & 0.209 & 0.1045 & 0.209 & 0.1003 & 0.480 & 0.1086 & 0.520 \\
\hline 276 & 0.336 & 0.168 & 0.084 & 0.168 & 0.081 & 0.480 & 0.0873 & 0.520 \\
\hline & Dibe & zepin & & & & & & \\
\hline 207 & 1.553 & 0.776 & 0.388 & 0.776 & 0.577 & 0.744 & 0.198 & 0.257 \\
\hline 224 & 1.300 & 0.690 & 0.345 & 0.690 & 0.513 & 0.744 & 0.177 & 0.257 \\
\hline & Dox & & & & & & & \\
\hline 208 & 1.870 & 0.935 & 0.4675 & 0.935 & 0.795 & 0.850 & 0.119 & 0.149 \\
\hline 254 & 0.350 & 0.174 & 0.087 & 0.174 & 0.148 & 0.850 & 0.026 & 0.149 \\
\hline 304 & 0.140 & 0.067 & 0.034 & 0.067 & 0.057 & 0.850 & 0.010 & 0.149 \\
\hline & Nortr & tilin & & & & & & \\
\hline 212 & 1.788 & 1.195 & 0.597 & 1.195 & 0.442 & 0.370 & 0.752 & 0.630 \\
\hline 241 & 0.852 & 0.403 & 0.201 & 0.403 & 0.149 & 0.370 & 0,094 & 0.630 \\
\hline & Trim & rami & & & & & & \\
\hline 212 & 1.324 & 0.662 & 0.331 & 0,662 & 0.529 & 0.799 & 0.132 & 0,199 \\
\hline 250 & 0.572 & 0.286 & 0.143 & 0.286 & 0.229 & 0.800 & 0.057 & 0.199 \\
\hline 276 & 0.176 & 0.088 & 0,044 & 0.088 & 0.071 & 0.807 & 0.018 & 0.205 \\
\hline & Opi & . & & & & & & \\
\hline 216 & 0.854 & 0.427 & 0.213 & 0.427 & 0.313 & 0.733 & 0.114 & 0.267 \\
\hline 256 & 1.046 & 0.523 & 0.261 & 0.523 & 0.382 & 0.730 & 0.140 & 0.268 \\
\hline & Clom & ramin & & & & & & \\
\hline 218 & 0.652 & 0.326 & 0.163 & 0.326 & 0.294 & 0.902 & 0.033 & 0.101 \\
\hline 254 & 0.190 & 0.092 & 0.048 & 0.092 & 0.082 & 0.891 & 0.009 & 0.0978 \\
\hline 276 & 0.157 & 0.075 & 0.041 & 0.075 & 0.067 & 0.893 & 0.008 & 0.107 \\
\hline & $\mathrm{Pr}$ & tilin & & & & & & \\
\hline 212 & 1.605 & 0.971 & 0.487 & 0.971 & 0.466 & 0,480 & 0.242 & 0.519 \\
\hline 228 & 1.385 & 0.699 & 0.343 & 0.699 & 0.336 & 0.481 & 0.175 & 0.521 \\
\hline 292 & 0.897 & 0.451 & 0.220 & 0.451 & 0.216 & 0.479 & 0.112 & 0.519 \\
\hline
\end{tabular}


Table. III.. Compounds with their quantities passing into water and octanol layers, partition coefficients and $\log \mathrm{P}$ values.

\begin{tabular}{|c|c|c|c|c|}
\hline $\begin{array}{c}\text { Comp. } \\
\text { code number }\end{array}$ & $\begin{array}{c}\text { quant. } \\
\text { in oct. }\end{array}$ & $\begin{array}{c}\text { quant. } \\
\text { in wa. }\end{array}$ & $\begin{array}{c}\text { Partition } \\
\text { coefficient }\end{array}$ & \multicolumn{1}{|c|}{$\log \mathrm{p}$} \\
\cline { 1 - 2 } & 2.58 & 2.42 & 1.0661 & 0.0278 \\
2 & 2.53 & 2.47 & 1.0242 & 0.0104 \\
3 & 2.40 & 2.60 & 0.9230 & -0.0347 \\
4 & 3.72 & 1.28 & 2.9062 & 0.4633 \\
5 & 4.25 & 0.75 & 5.6666 & 0.7533 \\
6 & 1.85 & 3.15 & 0.5873 & -0.2311 \\
7 & 4.00 & 1.00 & 4.0000 & 0.6020 \\
8 & 3.66 & 1.34 & 2.7313 & 0.4363 \\
9 & 4.48 & 0.52 & 8.6153 & 0.9352 \\
10 & 2.40 & 2.60 & 0.9230 & -0.0347 \\
\hline
\end{tabular}

$\log \mathrm{LD}_{\text {so(M.c.) }}$ and $\log 1 / \mathrm{LD}_{50(\mathrm{M} \cdot \mathrm{c.})}$ respectively. Graph II and Graph III represent better correlation lines as being perfectly parallel.

After the graphs have been completed, mathematical means have been calculated. Linear correlation equations have been derived for each of the two groups. The equations will be discussed later.

In thin layer chromatography studies a number of solvent systems reported before have been tried and sorted out according to the results. Some of them gave good results while the others did not. The solvent systems that gave good results have been listed in Table IV together with the $R_{f}$ values. In order to make a SAR study these solvent systems have been further investigated. No solvent system mentioned is good enough to give good $\mathrm{R}_{\mathrm{M}}$ values and to simulate biological medium, although some correlations with $R_{M}$ values have been attained with a less precision. Again these graphs show roughly the same pattern as Graph I.

\section{DISCUSSION}

In this research two parameters have been investigated for the SAR of tricyclic antidepressor compounds, the $\log \mathrm{P}$ and $\mathrm{R}_{\mathrm{M}}$.

Graph I which is constructed by using the $\log \mathrm{P}$ values and plotting them versus $\mathrm{LD}_{50}$ (Molar concentration) values shows good correlations and thus renders a relationship between biological effects and partitioning properties of the compounds. The correlations are linear. One can use these graphs directly for estimating 


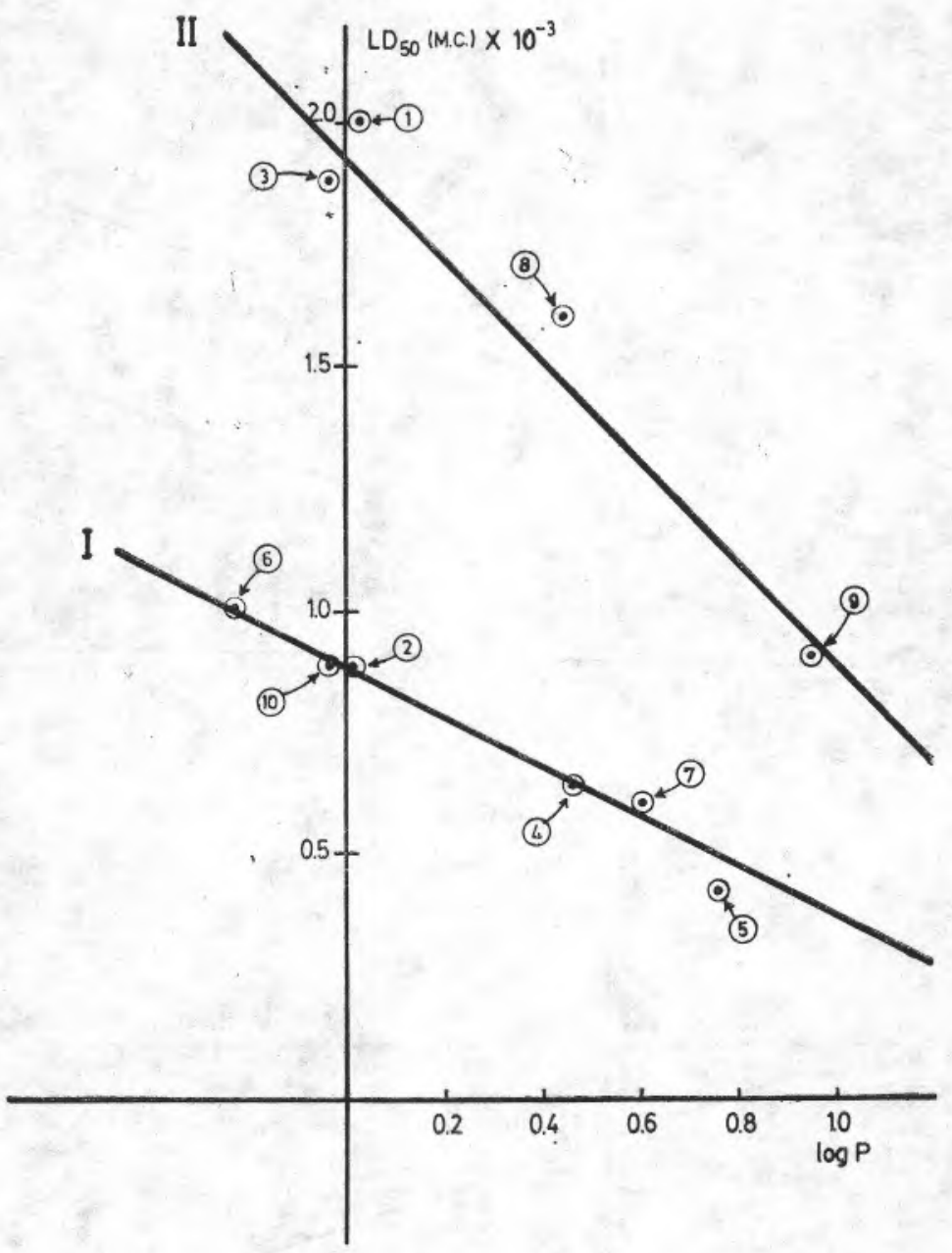

Graph I. $\log$ P versus $\mathrm{LD}_{\mathrm{s}_{0}}$ (M.c.)

the biologicaly effective doses of a new compound. It is also possible to derive the correlation equations of these lines. After constructing the correlation tables, Equation (I) and Equation (II) have been calculated for correlation lines I and II respectively. The equations have been given within $95 \%$ confidence intervals. 


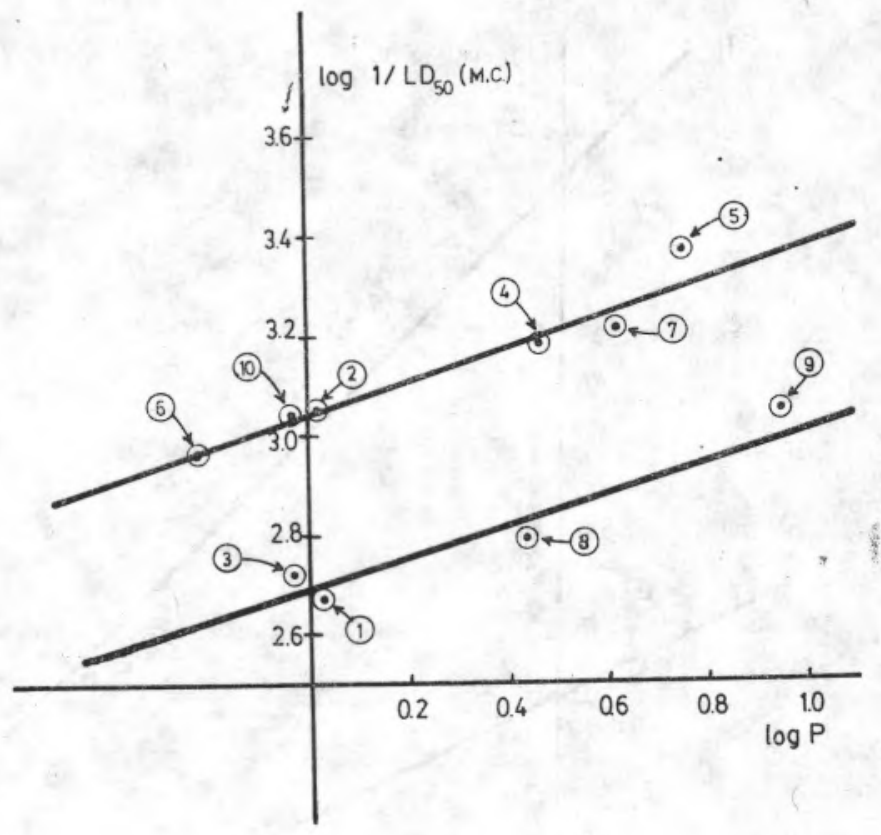

Graph II. $\log$ P versus $\log \mathrm{LD}_{50}$ (M.c.)

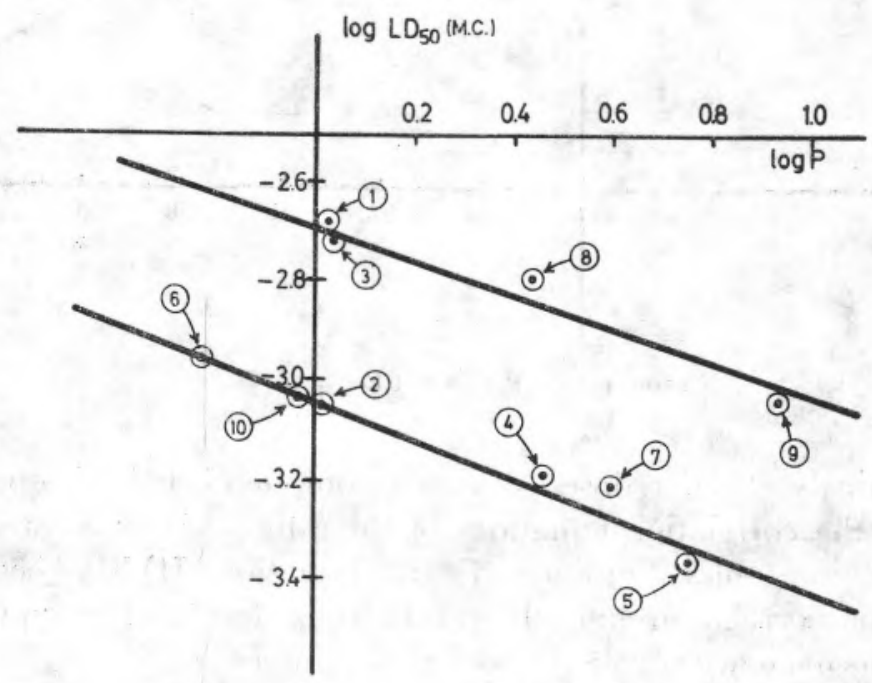

Graph III. $\log P$ versus $\log 1 / \mathrm{LD}_{\text {s0 }}$ (M.c.) 
Table IV. Solvent systems with appropriate $R_{f}$ values and compound code numbers

\begin{tabular}{|c|c|c|c|c|c|c|c|c|c|c|c|c|c|c|c|c|c|c|}
\hline $\begin{array}{l}\text { Compound } \\
\text { code } \\
\text { number }\end{array}$ & $\begin{array}{c}\text { Sol } \\
\text { sys. }\end{array}$ & $\mathrm{R}_{\mathrm{f}}$ & $\begin{array}{l}\text { Sol. } \\
\text { sys. }\end{array}$ & $R_{f}$ & $\begin{array}{l}\text { Sol. } \\
\text { sys. }\end{array}$ & $R_{f}$ & $\begin{array}{l}\text { Sol. } \\
\text { sys. }\end{array}$ & $R_{f}$ & $\begin{array}{l}\text { Sol. } \\
\text { sys. }\end{array}$ & $R_{f}$ & $\begin{array}{l}\text { Sol. } \\
\text { sys. }\end{array}$ & $R_{f}$ & $\begin{array}{l}\text { Sol. } \\
\text { sys. }\end{array}$ & $R_{f}$ & $\begin{array}{l}\text { Sol. } \\
\text { sys. }\end{array}$ & $R_{f}$ & $\begin{array}{l}\text { Sol. } \\
\text { sys. }\end{array}$ & $\mathbf{R}_{\mathrm{f}}$ \\
\hline 1 & A & 0.4815 & B & 0.5560 & C & 0.6404 & D & 0.5701 & E & 0.6448 & F & 0.4914 & G & 0.4672 & $\mathrm{H}$ & 0.7142 & $\mathrm{~J}$ & 0.2745 \\
\hline 2 & $\mathrm{~A}$ & 0.1698 & B & 0.9649 & C & 0.8455 & $\mathrm{D}$ & 0.2280 & $\mathrm{E}$ & 0.6880 & $\mathrm{~F}$ & 0.5746 & G & 0.6926 & $\mathrm{H}$ & 0.1904 & J & 0.5000 \\
\hline 3 & $\mathrm{~A}$ & 0.2430 & B & 0.3017 & C & 0.4228 & $\mathrm{D}$ & 0.2347 & $\mathrm{E}$ & 0.2056 & $\mathrm{~F}$ & 0.2500 & G & 0.1570 & $\mathrm{H}$ & 0.1238 & 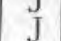 & 0.0980 \\
\hline 4 & $\mathrm{~A}$ & 0.2952 & B & 0.5238 & G & 0.5203 & D & 0.4561 & $\mathrm{E}$ & 0.5370 & $\mathrm{~F}$ & 0.5863 & G & 0.5041 & $\mathrm{H}$ & 0.4190 & $\vec{J}$ & 0.4019 \\
\hline 5 & A & 0.4811 & B & 0.8070 & C & 0.7624 & D & 0.2368 & $\mathrm{E}$ & 0.6388 & $\mathrm{~F}$ & 0.5259 & G & 0.8197 & $\mathrm{H}$ & 0.1714 & J & 0.5196 \\
\hline 6 & $\mathrm{~A}$ & 0.2430 & B & 0.4205 & $\mathrm{C}$ & 0.4797 & $\mathrm{D}$ & 0.2983 & $\mathrm{E}$ & 0.2752 & $\mathrm{~F}$ & 0.3103 & G & 0.1721 & $\mathrm{H}$ & 0.1333 & $\vec{J}$ & 0.1176 \\
\hline 7 & A & 0.7830 & B & 0.9260 & C & 0.4947 & D & 0.8421 & $\mathrm{E}$ & 0.8504 & $\mathrm{~F}$ & 0.1983 & G & 0.8511 & $\mathrm{H}$ & 0.8761 & $\vec{J}$ & 0.6372 \\
\hline 8 & A & 0.1852 & B & 0.2403 & C & 0.3333 & D & 0.2368 & $\mathrm{E}$ & 0.2523 & $\mathrm{~F}$ & 0.6379 & G & 0.2582 & $\mathrm{H}$ & 0.2190 & $\vec{J}$ & 0.3431 \\
\hline 9 & A & 0.2361 & B & 0.7009 & C & 0.7317 & D & 0.6754 & $\mathrm{E}$ & 0.7570 & $\mathrm{~F}$ & 0.5603 & G & 0.6639 & $\mathrm{H}$ & 0.1333 & $J$ & 0.4215 \\
\hline 10 & A & 0.1404 & B & 0.2803 & $\mathrm{C}$ & 0.3984 & $\mathrm{D}$ & 0.1842 & E & 0.1401 & F & 0.2069 & G & 0.0909 & $\mathrm{H}$ & 0.1238 & J & 0.0784 \\
\hline
\end{tabular}

Solvent systems

A) Ethanol/Carbontetrachloride $(16: 84)$

Reference
B) Diethylether/Aceton/Ethylacetate/Diethylamin (85:11:2:2)
C) Benzene/Aceton/Diethylamin (50:10:5)
D) Benzene/ Diethylether/Aceton/Ammonia (35:35:35:1)
E) Chloroform/Aceton/Ammonia (50:50:1)
F) Aceton/Methanol/ Ammonia (50:50:1)
G) Aceton/Ammonia (99:1)
H) Dioxan/ Benzene/Ammonia $(7: 12: 1)$
J) Chloroform/Methanol/ $\quad(90: 10)$ 


$$
\begin{aligned}
& \mathrm{LD}_{\text {50(M.e. })}=-0.599(\mp 0.136) \log \mathrm{P}+0.917 \text { (F 0.061) } \\
& \mathrm{n} \quad \mathrm{r} \quad \mathrm{s} \\
& 6-0.987 \quad 0.132 \\
& \mathrm{LD}_{\text {s0(M...) }}=-1.11(\mp 0.86) \log \mathrm{P}+2.00(\mp 0.44) \\
& n \quad \mathrm{r} \quad \mathrm{s} \\
& \begin{array}{lll}
4 & -0.969 & 0.152
\end{array}
\end{aligned}
$$

It is quite evident from Eq. (I) that the correlation among the first group is very good. The correlation coefficient is quite close to 1 , $\mathrm{s}$ value is quite small and $\mathrm{r}^{2}$ is also big enough. Also in the second group the correlation is good. As the correlation coefficients of both lines are negative these are negative correlations. The equations derived from $\log 1 / \mathrm{LD}_{50(\mathrm{M} . c .)}$ versus $\log \mathrm{P}$ tables are better as predicted.

In thin layer chromatography studies a number of solvent systems gave good separations. But only a few of them gave same $R_{M}$ vs. $\mathrm{LD}_{50(\mathrm{M} . . .)}$ correlations comparable to that of $\log \mathrm{P}$ vs. $\mathrm{LD}_{50}$. The correlations thus obtained are not as good as Graph I, but still show almost same pattern. Here again there are two correlation lines.

After the construction of graphs mentioned before and derivation of the equations (I) and (II) it is now possible to estimate roughly effective doses of a new compound belonging to same structural class and having same chemical properties. One can make such estimations simply by finding the partition coefficient and placing it on the graph or inserting it into the equations (I) and (II). As there are two correlation lines or two equations one should find two values of which one is expected to be very close to the actual value. Considering the cost of biological tests and efforts involved, this saves a lot of time and unneglectable waste of material. In fact for a number of compounds treated there are more than one $\mathbf{L D}_{50}$ values reported $(21,23,25)$ although they are all determined in mice by oral teatment. At first this seemed somehow odd but after obtaining the results of this research one can make some assumptions which seem perceivable. In Graph $I$ the only $\mathbf{L D}_{50}$ values which show a perfect correlation have been given but there are also other values reported which shift and come closer to the other line of correlation. This 
seems possible only if there are more than one mechanism of action or more then one enzyme species with which these compounds interact.

Starting from this assumption now it becomes possible to explain the confusion on chromatography plates which have been run with different solvent systems. As it has already been mentioned the compounds show different $R_{f}$ values with even slightly different solvent systems although necessary precautions have been taken to bring the starting material at $\mathrm{pH} 7.8$ still they look more or less like Graph I. It is quite evident from tlc studies that particularly Compounds number 2, 6,7 and in a few cases Compound 1 show shifts. In one solvent system some of them seem to be closer to correlation line I and in another solvent system they seem to be closer to correlation line II. This miqht be a reason why more than one $\mathrm{LD}_{50}$ have been reported before particularly for those compounds.

\section{SUMMARY}

In this research structure activity relationship of tricyclic antidepressor compounds have been studied using $\log \mathrm{P}$ and $\mathrm{R}_{\mathrm{M}}$

After determining the partition coefficients and $\log \mathrm{P}$ values they have been plotted versus $\mathrm{LD}_{50}$ values reported in literature and graphs have been constructed.

On the graph thus obtained there are two lines of correlation. Six compounds build one of the correlation lines and four build the other. Also correlation equations have been derived after constructing the correlation tables. The equations have good $\mathrm{r}$ values and small $s$ values.

A series of tlc studies has shown that a similar correlation can also be produced on tlc plates with a poorer precision. Also the equations derived thereof have smaller $\mathrm{r}$ values and larger $\mathrm{s}$ values.

Looking at the results obtained with $\log \mathrm{P}$ vs. $\mathrm{LD}_{50}$ plotting and several $R_{M}$ vs. $L_{s 0}$ plotting one can bring some comments on the variances in reports about the $\mathrm{LD}_{50}$ values of these compounds. 


\section{ÖZET}

Bu araştırmada $\log \mathrm{P}_{\text {ve }} \mathrm{R}_{\mathrm{M}}$ parametreleri kullanlarak trisiklik antidepresör bileşikler arasındaki yapı etki ilişkileri incelenmiştir. Bileşiklerin dağılma katsayıları saptandıktan sonra bunların logaritmaları literatürde verilmiş bulunan $\mathrm{LD}_{50}$ değerlerinin molar konsantrasyonlarına karşı çizilerek grafik hazırlanmışur. Bu şekilde elde edilen grafikte iki lineex korelasyon doğrusu görülmektedir. Bu doğrulardan birisi üzerinde bileşiklerden alısı yer almaktadır. Diğer dördü ise ikinci korelasyon doğrusunu oluşturmaktadır. Bu doğrular için kullanulan bilgilerden yararlanarak korelasyon tabloları oluşturulmuş ve korelasyon denklemleri hesaplanmıştır. Korelasyon denklemlerinin $\mathrm{r}$ değerleri l'e oldukça yakındır, s değerleri ise küçüktür. Ayrıca bir seri ince tabaka kromatografisi çalışması ile yukarıda adı edilen grafiğe benzer sonuçlara ulaşılmıştır. Bu grafiklerde de yine iki korelasyon doğrusu görülmektedir. Ancak bu doğru$\operatorname{lar} \log \mathrm{P}_{\mathrm{x}} \mathrm{LD}_{50}$ grafiğinden elde edilen kadar sağhılı değildir. Bunların denklemlerinin $\mathrm{r}$ değerleri daha küçüktür, s değerleri ise daha büyüktür.

Bu çalışma ile hem pratik alanda yararlanabilecek bir sonuç elde edilmiştir, hem de ilaçların etki mekanizmalarına özge bir davranışa dikkaı çekilmiştir. Pratik alanda yararlanış, bu gruptan yeni sentez edilen bir bileşiğin biyolojik sistemde denenmesi gereken dozunu kabaca saptamak yönünden mümkündür. Yeni yapilan bir bileşik için kolay bir çalışma ile dağılma katsayı̊ı saptandıktan sonra bu değeri grafikte ya da denklemde yerine koyarak biyolojik sistemde etkili olabilecek dozu hakkında kabaca bilgi edinmek mümkündür. $\mathrm{Bu}$ hem parasal yönden hem de yitirilen çaba ve zaman yönünden yararlar sağlamaktadır.

Bunun yanı sıra literatürde bu gruptan bazı bileşikler için birden fazla $\mathrm{LD}_{50}$ değerinin verildiği görülmektedir. Her ne kadar bu değerlerin tümü farede ve oral yolla saptanmış ise de birbirlerinden önemli ayrucalıklar göstermektedir. Yapılan bu çalışmada adı geçen değerler ayrı ayrı yerine konulduğunda bir kismının I Nolu doğru üzerinde yer almasına karşın diğerlerinin II Nolu doğru üzerinde yer aldığı görülmüştür. Böyle bir durum için bileşiklerin organizmada değişik iki etki mekanizması ile etkilerini göstermesi ya da organizmada değişik iki enzim ile etkileşmeleri sỏz konusu olabilir. Ayn özelik yapilan bír serí ince tabaka kromatografisi çalış- 
maları ile de gösterilmiştir. Burada daha belirgin olarak özellikle birden fazla $L_{50}$ değeri verilmiş bulunan bileşikler değișkenlik göstermekte bazan I Nolu doğxuya bazan da II Nolu doğruya yakın yex almaktadırlar.

\section{REFERENCES}

1 - Davis, J. M., G. L. Klerman, J. J. Schildkraut., Drugs Used in the Treatment of Depression. (Sec. on Psychosomatic Med., Nat. Ins. Mental Health, Bethesda, Md.) U.S. Public Health Service, 1836, 719 (1967).

2 - Schmid, E., E. Hoppe., Chr. Meythaler und L. Zicha., Arzneim.-Forsch., 13, 969 (1963).

3 - Thomas, J. J. et L. Dryon., J. Pharm. Belgique, 22163 (1967).

4 - Viala, A., F. Gouezo et C. Gola., J. Chromalog., 45, 94 (1969).

5 - Gawrych., Z., Farmacja Polska 1, 23 (1971).

6 - Röder, E., E. Mutschler, H. Rochelmeyer., J. Chromatog., 42, 131 (1969).

7 - a Marca, J., H. Mühlemann., Pharm. Acta Helv., 46, 558 (1971).

8 - Noirfalise, A., J. Chromatog., 20, 61 (1965).

9 - Lagubeau, J., R. Crockett et P. Mesnard., Bull. Soc. Pharm. Bordeaux, 110, 10 (1971).

10 - Beyer, K. H., und D. Klinge., Arzneim. - Forsch., 19, 1759 (1969).

11 - Ahuja, S., G. Spitzer and F. R. Brofazi., 7. Pharm. Sci., 57, 1979 (1968).

12 - Slunjski, M. et I. Turkovic., 7. Pharm. Belgique,, 25, 400 (1970).

13 - Dunn, W. J., S. Wold., F. Med. Ghem., 21, 1001 (1978) and ref. therein cited.

14 - Hammett, L. P., Physical Organic Chemistry, ICS McGraw-Hill Book Company Inc. New York - London (1948).

15 - Yamamato, T. and T. Otsu., Chem. Ind., (London) 787 (1967).

16 - Hansch, C., J. Med. Chem., 11, 920 (1968).

17 - Swain, C. G. and E. C. Lupton., 7. Amer. Chem. Soc., 90, 4328 (1968).

18 - Friedrich, H. J., Angew. Chem., 77, 721 (1965).

19 - Hansen, O. R., Acta. Chem. Scan., 16, 1593 (1962).

20 - Hansch, C., A. Vittoria, C. Silipo. and P. Y. C. Jow., J. Med.Chem,, 18, 546 (1975).

21 - Eriksoo, E. and O . Rohte,, Arzneim.-Forsch., 20, 1561 (1970).

22 - Clarke, E. G. C., Isolation and Identification of Drugs, The Pharmaceutical Press (1969).

23 - Jirkovsky, I., J. G., Humber, K. Voith and M. D. Charest., Arzneim.-Forsch. 27, 1642 (1977).

24 - Sunshine, I., Handbook of Analytical Toxicology, The Chemical Rubber Comp. (1969).

25 - Ribbentrop, A. und W. Schaumann., Arzneim.-Forsch., 15, 863 (1965).

26 - "Anafranil" Clomipramine, Geigy, ASA-Orhanlar 8952 and references therein cited. 


\section{BIILIMSEL HABERLER}

\section{Tezler:}

1. Ecz. Maksut Goşkun

“Türkiye'de yetișen Dryopteris ve Asplenium türleri üzerinde Farmasötik Botanik yönünden araştırmalar" Doktora Tezi (1978).

2. Dr. Pharm. Nurşin Gönül

"Sülfametoksazolün değişik kristal şekillerinin (polimorflarını) çözünme kinetiğinin incelenmesi" Doçentlik Tezi (1978).

3. Dr. Pharm. Seçkin Özden

“3 H-Imidazo (4,5-b) ve (4,5-c) piridinlerin 2-alkil türevlerinde nicel yönden yap1 etki bağdaştırılması üzerinde araştırmalar" Doçentlik Tezi (1978).

4. Dr. Sci. Inci Ödün

"Rutenyum elekrotla hidrokinonun anodik oksidasyonu ve kinonun katodik redüksiyonunun incelenmesi" Doçentlik Tezi (1978).

\section{Ders Kitaplar1:}

1. "Farmasötik Botanik II. baskı" Prof. Dr. Kâmil KARAMANOGLU, A.Ü. Ecz. Fak. Yayınları No: 44, A.Ù. Basımevi, Ankara 1977.

2. "Farmasötik Kimya" Prof. Dr. Michel BERTUGAT ve Dr. Pharm. Rahmiye ERTAN, A.Ủ. Ecz. Fak. yayınları, No: 45, A. Ù. Basımevi Ankara 1975.

3. "Mesleki Latince I. bask"” Prof. Dr. Nevin TANKER ve Dr. Heinrich BRUNNER, A.U். Ecz. Fak. yayınları, No: 47, A.Ư. Basımevi, Ankara 1977. 


\section{Seminer, Konferans ve Kongreler:}

Dr. Pharm. Bilge ŞENER, 28-29 Kasım 1977 tarihlerinde Istanbul'da yapılan "Sivı Kromatografisi" isimli seminere bir bildiri ile katılmıştır.

Dr. Pharm. Kandemir CANEFE, 24 Nisan 1978 tarihinde Ankara'da yapılan "Çağdaş Eczacının Halk Sağlığındaki Rolü" isimli panele bir bildiri ile katılmıştır.

Dr. Pharm. Nedret KILIÇ, 12-14 Ekim 1977 tarihlerinde Ankara'da yapılan II. Ulusal Biyokimya Kongresine bir bildiri ile katılmıstır.

Iskenderiye Úniversitesi Profesörlerinden Prof. Dr. Youssef RIAD, 20 Mart 1978 tarihinde Fakültemizde, Organik Kimya ile ilgili bir konferans vermiştir.

17-21 Ekim 1977 tarihlerinde Ankara'da yapılan TỬíTAK VI. Bilim Kongresine,

Prof, Dr. Gazanfer BINGÖL, Ecz. Nilgün ALTAN, Ecz. Zeliha KOÇER

Prof. Dr. Enver IZGÜ, Dr. Pharm. Kandemir CANEFE

Prof. Dr. Enver IZGUU, Dr. Pharm. Necati DIKMEN

Prof. Dr. Enver IZGÜ, Dr. Pharm. Nilüfer TARIMGI

Prof. Dr. Mekin TANKER, Dr. Pharm. Bilge ŞENER

Prof. Dr. Nevin TANKER, Dr. Pharm. Gülden SEZİK

birer bildiri ile katılmışlardır.

25-27 Mayıs 1978 tarihlerinde A. Ú. Eczacılık Fakültesi ve H.Ủ. Eczacılık Fakültesi Farmakognozi Kürsülerince hazırlanan ve A. U. Eczacılık Fakültesinde düzenlenen II. Bitkisel Ilâç Hammaddeleri Toplantısına,

Dr. Pharm. E. ATASÜ, Dr. Pharm. I. KILIÇER (A.Ü.)

Prof. Dr. A. BAYTOP (1.Ü.)

Prof. Dr. T. BAYTOP, Doç. Dr. G. SARIYAR (I.Ü.)

Doç. Dr. A. CEYLAN (E.Ü.)

Doç. Dr. A. GEYLAN, Y. OZANSOY (E.Ü.)

Prof. Dr. B. ĢUBUKÇU, Ecz. T. DORTUNÇ (I.Ü.)

S. DOĞANCA (1.Ü.)

Prof. Dr. K. G. GƯVEN (I.Ú.), Ecz. G. HAKYEMEZ (E.Ủ.)

Prof. Dr. M. H. IŞIKAN (A.Ü.)

Prof. Dr. K. ILISULU (A.Ü.)

Ecz. A. H. MERIÇLI (I.Ü.)

Doç. Dr. N. NOYANALPAN (A.Ủ.) 
Doç. Dr. S. ÖKSÜZ, Prof. Dr. A. ULUBELEN (t.Ü.)

Doç. Dr. G. SARIYAR (I.Ü.) J. D. PHILLIPSON (Londra)

Doç. Dr. E. SEZİK, Dr. Pharm. İ. ÇALIŞ (H.Ü.)

Prof. Dr. M. TANKER, Dr. Pharm. M. YENEN (A.Ü.)

Prof. Dr. M. TANKER, Prof. Dr. N. TANKER, Dr. Pharm. N. ÖZKAL (A.Ü.)

Prof. Dr. M. TANKER, Dr. Pharm. F. TOSUN (A.Ü.)

Prof. Dr. N. TANKER, Dr. Pharm. M. COȘKUN (A.Ü.)

Prof. Dr. A. ULUBELEN, N. ATEŞ (1.Ü.) T. NISHIDA (Stokholm)

Y. Kim. Müh. N. VAN (R.S.M. Hıfzıssıhha Ens. - Ankara)

birer bildiri ile katılmıșlardır. 


\section{Fakülte Profesörler Kurulunun 10.3.1970 tarih ve 358 sayılı Kararı ile Fakülte Mecmuasında yayınlanacak yazılar için tesbit edilen esaslar}

1) Dergide, bașka bir mecmuada aynı isimle ve aynı tarzda neşredilmemiş orijinal çalışmalar yayınlanır.

2) Yazılar Komisyona verildiği tarih sırasıyla yayınlanır.

3) Metin 15 daktilo sayfasını geçmemek üzere Türkçe veya yabancı dilde yazılabilir. Metin bașlığı ve özeti Türkçe ve yabancı dilde yazılacaktır.

Yabancı dilde yazılmış başlık, metin ve özetlerin dil kurallarına uygun olmasının temini, yazara aittir.

4) Yazılar, kâğıdın bir yüzüne, daktilo ile ve normal aralıkla yazılmalı, italik yazılacak kelimelerin altı çizilmeli, klişesi yapılacak grafik, şema, formül gibi şekiller, çini mürekkep ile, aydinger kâğıdına çizilmeli; fotoğraflar parlak kâğıda ve kontraslı olarak çekilmelidir. Şeki!lerin her biri ayrı kâăıtlarda olmalı ve kâğıdın üzerinde yazarın adı, kaçıncı şekil olduğu, resim altı yazılması istenen ibare kaydedilmelidir.

5) Yazı plânı aşağıdaki șekilde olmalıdır: Konunun takdimi, bulgular, denel kısım, münakaşa, Türkçe özet, yabancı dilde özet, literatür.

Konunun takdimi 2 daktilo sahifesini geçmemeli; materyal, metot ve yapılan ameliyeler "denel kısım" da yer almalı, "münakaşa" kısmı, gerekli ise konmalıdır.

Literatür, metinde parentez içindeki numaralarla belirtilmesi ve metin sonunda bu numaralara uygun olarak sıralanmalıdır. Sırasıyla yazarın soyadı, adının ilk harfi, mecmuanın milletlerarası kullanılan kısaltılmış ismi, cilt numarası (italik), sayfa ve parentez içinde tarih yazılmalıdır.

6) Tashihler yazar tarafından yapılacaktır.

7) Yazara 50 ayrı baskı verilir. 